\title{
COMMENT
}

\section{ALWAYS A BORROWER: LAW AND OTHER DISCIPLINES $\dagger$}

\author{
Phillip AREedA*
}

Over fifty years ago, Oliver Wendell Holmes declared that "the black-letter man may be the man of the present, but the man of the future is the man of statistics and the master of economics." Today, few would doubt that the men and women of the law-whether teachers, practitioners, or judges-need to understand not only legal doctrine but also philosopliy, political science, economics, sociology, psychology. I could go on, for there is no stopping point in a catalogue of disciplimes relevant to the law.

\section{I}

The layman would be surprised by this, for $11 \mathrm{e}^{2}$ views the law-both statutory and common law, if he is aware of the difference-as a selfcontained array of detailed rules, like the Internal Revenue Code. The source of this lay view is easy to understand. Most citizens lave little conscious contact with the law beyond traffic or tax regulations or occasional news stories about a Supreme Court pronouncement. (I say "pronouncement" not to put the Court's reasoning in issue, altliough one might in some cases, but to emphasize the legislative tone of most news reports about judicial decisions.) In addition, the layman may be excused for thinking the law clear and definite, for judges often write their decisions as if the problems before them were already answered by existing legal rules or their logical implications.

Why judges write this way is itself an interesting question. A cynic might suppose that all professionals cloak their work in a vocabulary and technique that non-professionals feel unqualified to penetrate. Perhaps unelected judges feel uncomfortably undemocratic in making law. They

$\dagger$ This Comment is a version of the 1988 Currie lecture, delivered at Duke Law School on April 7, 1988.

* Langdell Professor of Law, Harvard Law School.

1. O.W. Holmes, The Path of the Law, in Collected Legal PAPERs 167, 187 (1920).

2. I use such words as "man" or "he" in their universal, not gender-specific, senses. 
might also fear that public acceptance of their decisions would be lessened if the public, or losing hitigants, realized the extent of their pohcymaking discretion. Moreover, the impulse to. "do justice" in a particular case inay call for a result that a judge feels unwilling or unable to articulate in terms of underlying policy. Indeed, in some cases the final step in applying a general standard may reflect an unarticulable judgment.

Though laymen may thus be shielded from the lawmaking powers actually exercised by judges, everyone in the law knows that the certainty expressed in many judicial opinions is a mere rhetorical convention. Well, almost everybody. Astonishingly, some "avant-garde" law professors proclaim that less advanced academics and judges are "formalists" who misconceive the law as a closed, self-contained system of determinate legal rules. At least that is the message perceived by some students who surprise theinselves by deducing that I am a member of that avantgarde group. Meinbership is inferred from iny msistence that legal standards are often in tension, pointing in opposite directions, and that such tensions can be resolved, as Holnes said, not by logic alone but by experience in applying a rule or standard to achieve a social purpose. ${ }^{3}$

If that insistence has not always been commonplace, it surely is today. We are all products of the legal reahist movement of the 1930s, which focused the profession's attention on the inevitable role of public policy in the law. The legal realists emphasized that legal doctrine is not as firm as it sonetines pretends to be. There is a chaotic or random element, as reflected in the caricature that legal results depend less upon "the law" than upon the judge's digestion. The realists' more important contribution was their emphasis on the purposive function of law. Every legal rule either once had some policy function or inust be assigned one in order to decide when and how to apply it. Of course this was not new, even in the 1930s. We have already noted a few of Holnes's comments, and we might add Karl Llewellyn's explanation of the "grand tradition" of the great coinmon law judges. ${ }^{4}$

Judicial opinions might be dryly and doctrinally deductive in appearance, but the results reflect judges' beliefs or assumptions about what accomplishes sound public policy, whether articulated or not. Indeed, the very language in which we speak about legal rules and objectives reflects the organization and beliefs of the society in whicli we live. The law professors characterizing thenıselves as the Critical Legal Studies movement are thus quite conventional in recognizing tliat law is not a

3. O.W. Holmes, The Common Law 5 (M. Howe ed. 1963).

4. K. Llewellyn, The Common Law Tradition dedication (1960). 
self-contained mathematical science, that it rests on premises and social conventions about appropriate family, busmess, and social relationships and about the proper relationships of individuals to each other and to the state. They go beyond these rather commonplace propositions and draw upon "post-structural" studies of language to emphasize, again correctly, that legal language and inodes of legal discourse reflect the society in which we hive, including its conventions and premises. Our very language of "rights" and "property" embodies the assumptions of the hiberal democratic capitahistic order. The "Crits" emphasize that the present orgaunzation and assumptions of the existing social order are not the only ways of structuring a society, which again is true enough. But there is nothing startling or revolutionary about the proposition that our law reflects the premises of our society. How could it be otherwise?

What is distinctive about some nembers of that movement is their belief that the existing social order is "oppressive"; they prefer some radically different ordering of society, although they have not yet identified and defended their preferred alternative, except in rather vague if not utopian terins. Nor does "law" or "legal reasoning" or any other characteristic of the legal profession or legal scholarship seem especially pertinent to the question whether capitalism or hiberal democratic political processes should be replaced with socialism, Marxism, communitarianism, or something else. It therefore seeins somewhat surprismg that such talk is found at law schools rather than in those faculties where advanced traming about economics or political science might better equip scholars to pursue those questions. The proverbial visitor from Mars might be surprised to see the ramparts against liberal democratic capitalisin staffed by law professors rather than by those who know more about economics, sociology, philosophy, and the like.

Even those of us who do not regard our society as fundamentally oppressive understand that operating the legal system we have requires close attention to the learning provided by other disciphines. This is so widely accepted today as to be second nature to law teachers. Indeed, we now wonder whether "law" is anything other than a combination of economics, philosophy, political science, statistics, semantics, and other disciplines.

If the responsibilities of courts were relatively small in magnitude and narrow in range, then perhaps law could be more closely confined to classical doctrines about springing uses or the availability of specific perforinance to enforce contracts. In that event, a modest infusion of more general learning might suffice. In fact, however, ours is a litigious and law-ridden society in which we expect courts to address and resolve questions that most other societies allocate to their poitical branches-the 
operation of schools, the apportionment of legislatures, or the competitiveness of the economy. Not only do our courts occupy a peculiar role in administering the Constitution, but our legislatures are willing to legislate in extremely vague terms that delegate enormous policymaking discretion to the courts. In addition, of course, contemporary judges continue to expand the common law. The resulting quantity of judgemade law applying to such a wide range of affairs is staggering, as is the variety of knowledge necessary to deal with it.

And that's the rub: how is the learning of other disciplines received into the law? The answer to that question will mevitably take us back to what law students learn and what law teachers study. In tle course of seeing how the law receives other disciplimes, we can also ask whetler the law should simply abdicate to psychologists, economists, and other experts.

\section{II}

Because the law touches all aspects of life, judges recognize that they cannot resolve all the controversies before them without resort to the learning of other disciplines. The decision that racially separate education was not equal education rested not only on the moral repugnance of racial classifications, but also on sociological studies showing the detrimental psychological effects of separateness as a badge of inferiority. Various other constitutional rules reflect judgments about how voting schernes actually function. Legal rules about the admissibility of lie detector or blood test results rest on judicial acceptance of certain scientific views about the reliability of such tests. Legal rules defining the scope of the "insanity defense" to criminal liability rest on a complex interplay of judgments about the purposes of criminal punishment, the pliilosophical concept of noral responsibility for one's acts, and psychological learming about nental illnesses and their impact on liuman choices. Emerging rules about unconscionability or good faitl in contracts are strongly affected by assumptions about how markets actually work and about the likely market consequences of enforcing, or refusing to enforce, contracts as written. And nost of the legal rules implementing the antitrust laws and public utility regulations are strongly affected by economic theory, as well as by enipirical studies of actual markets.

These exaniples, which could be multiplied endlessly, illustrate the influence of other disciplines at the "mega-level" of rule fonnulationthe use of learning fron 1 other disciplines to help frame a general legal rule. At the "micro-level" of rule application and factfinding, the courts are besieged by experts testifying about whether a particular defendant is insane, has nianufactured a "safe" product, exercised common medical 
skill, discriminated in einployınent, priced below cost, worsened competition, or possessed a "inonopoly."

In antitrust cases, for example, good econoinic experts are often invaluable at collecting data, inassaging thein into a ineaningful story, and interpreting them. Experienced in a particular market area, they may know what kinds of data exist in published or unpublished form. Although $I$ ain not entirely a novice in antitrust matters, $I$ have always been impressed by those who have the sense of what information can be found, as distinct from the very expensive process of creating it from scratch. A particularly valuable talent, moreover, is the ability to draw reasonable inferences from limited fraginents of data. When we cannot find information bearing directly on the question we wish to answer, there may be some surrogate for it that the imaginative and experienced economist can identify and find. Doing so requires both innagination and theories about how one thing is connected to another in the inarketplace, which is at least one of the things that economics is about. As the next step, those who are knowledgeable in statistical techiriques know how to assemble the available data in a form inost likely to give them ineaning. Finally, the data must be explained, which a market expert is often in the best position to do.

Such expert testnnony is the most obvious ineans by which courts learn what other disciplines have to innpart. Experts are most coininonly used to help apply an existing rule to the facts of a particular case, but their contribution can also influence the shape of the rule itself: experts may persuade the judge that the received rule needs revision or, inore frequently, that a general standard should be suppleinented witl a limitmg or expanding presumption to aid in its implementation.

In all events, what is the tribunal to make of conflicting experts? The practicing hitigator's usual answer is very sinnple: each side produces its own expert and attempts to impeach the other's by finding inconsistencies within his testimony or between his present and past pronouncements. Although each expert might candidly disclose the factual or intellectual weaknesses of his chent's position, I've never seen such a case. In the typical adversarial inodel, each side presents its positives and negatives in the best light possible, leaving the jury to choose among conflicting experts' opinions. Seemg no other way, litigants are resigned to this process, as are many judges, even the inany judges who say privately that they trust none of the experts who have appeared in their courts.

As a student of antitrust law, I have read inany cases with shameless expert testimiony. Soinetimes, this testimony is little inore than the factual and legal assertions of a lawyer's brief. Such a brief, masquerading as testimony, asserts a party's contentions of fact as if they were estab- 
lished facts and presents a party's legal characterizations and conclusions as if they too were established facts. Unfortunately, when the lawyer succeeds in disguising his arguments as an expert's opinion, juries may fail to apply the same discounts they would apply to a lawyer's contentions and arguments.

There is no outlandisli position that some so-called expert cannot be paid to espouse. Some psychiatrists will testify that an ax murderer was just a.slightly mixed-up Mother Theresa. Let me give a few examples that require little economic sophistication to ridicule, juxtaposing rather obvious facts with an expert's straight-faced utterance.

Fact: Sellers obeying the iron law of the market naturally prefer to sell a given supply to those offering the higliest price.

Expert opinion: An econounist declared in one case that a seller "restrained trade" by selling his product to customers offering higher prices rather than to tliose offering lower prices.

Fact: A shipper contracted to pay a pipeline for the riglit to have its gas transported for twenty years whether or not it actually slipped any gas. The pipeline's prices were not fixed but, subject to government regulation, were determined solely by the pipeline.

Expert opinion: An economist persuaded a jury and a court that the shipper was the "owner" of the pipeline, with a greater economic interest in it than the firm that wholly owned it. ${ }^{5}$ This is expert testimony not as fact or law, but as fancy.

Fact: When a group of competitors agree that they will abandon a certain credit term-for example, no interest charge for payment withm 30 days-they have fixed an element of price. Expert opinion: Economists persuaded a court of appeals that the conspiracy in question could promote competition because ehiminating credit "sharpened the focus on price" and made new entry easier. ${ }^{6}$ This is an example of the partial truth that deceives. It is true that eliminating competition in credit, delivery terins, warranties, or other elements of the sale does sharpen the focus on the only element of competition remaining, price. However, doing so facilitates the enforceinent of any

5. See Trial Record at 1480-81, Colorado Interstate Gas Co. v. Natural Gas Pipeline Co., 661 F. Supp. 1448 (D. Wyo. 1987) (No. C34-139-B), appeal pending.

6. See Catalano, Inc. v. Target Sales, Inc., 605 F.2d 1097, 1099 (9th Cir. 1979), rev'd per curiam, 446 U.S. 643 (1980). 
hidden express agreement on price and facilitates tacit coordination of prices; only the tooth fairy would believe that competitors have eliminated competition on credit for the purpose of intensifying competition on other price terms. As for new entry, it is an acknowledged procompetitive force, and eliminating credit means that new entrants will not lave to provide it and thus can enter with less capital. What the economists did not mention to the court was that high cartel prices also encourage entry-as the oil-producing countries have discovered-although cartel pricing has never been regarded as procompetitive on that account.

Fact: A distributor might be harmed by having to pay a higher price for his goods than he paid previously, but lie cannot be harmed by the availability of a lower price to a distributor who is located in a different part of the country and who does not compete with him.

Expert opinion: An expert based an elaborate damage calculation-which the jury and the judge accepted-on just such a discrimination, which, logically, could not injure the plamtiff at all. ${ }^{7}$

Fact: If a group of television manufacturers in Japan fix high prices at home, they will sell fewer television sets there. They may then have idle capacity that can be profitably used to sell television sets elsewhere, mcluding the U.S., even if the price only barely exceeds their marginal cost. But the assumed highprice conspiracy in Japan generates no incentive or ability to sell below cost in the Umited States and, mdeed, can have no effect at all when export capacity in Japan has expanded many times over the relevant period.

Expert opinion: An economist made much of the high-priced conspiracy in Japan as circumstantial evidence of a conspiracy by the Japanese manufacturers to charge low prices in the Umited States. A court of appeals, ${ }^{8}$ along with several dissenters in the Supreme Court, ${ }^{9}$ thought that expert's view sufficient

7. See Best Brands Beverage, Inc. v. Falstaff Brewing Corp., 653 F. Supp. 47, 54 (S.D.N.Y. 1985), rev'd, 842 F.2d 578, 585-86 (2d Cir. 1987).

8. Zenith Radio Corp. v. Matsushita Elec. Indus. Co. (In re Japanese Elec. Prods. Antitrust Litig.), 723 F.2d 238, 310 (3d Cir. 1983), rev'd, 475 U.S. 574 (1986).

9. Matsushita Elec. Indus. Co. v. Zenith Radio Corp., 475 U.S. 574, 599 (1986) (White, J., dissenting, joined by Brennan, Blackmun, \& Stevens, JJ.). 
to support a hypothetical jury verdict of a low-price conspiracy in the U.S. (and thus to create a triable issue).

And I say nothing about the psychiatrist who testified that eating a lot of Twinkies caused a deep depression that established dinninished responsibility for killing another, ${ }^{10}$ or the psychiatrist who never examined or even interviewed a certain mother or daughter (then dead) and yet testified on the basis of what he called a "psychological autopsy" that the mother caused the daughter's suicide.

If we assume that all these witnesses qualified as experts, it follows either that the conventional standards of expert qualification are too lax to protect the courts from the inexpert, or that the prevailing ethics of many expert witnesses are insufficient to protect the courts from charlatans.

What can be done about it? I sometimes have the impractical dream that experts will be forced to publish their testimony in professional journals for the ridicule of their peers. A somewhat more practical dream is that judges will exercise greater supervision over the credence that juries are allowed to give experts and will even criticize experts by name in published judicial opinions. But many judges hesitate either to control or to criticize. Experts are an inevitable part of the factfinding process, which many judges regard as within the primary, if not exclusive, domain of the hitigants and jury. And the judge is a generahist-even more so than the legal academic, who, though only a lawyer, devotes his professional life to a single subject or two. Without deep familiarity with each of the many subjects he encounters, the judge may not be selfassured enough to rule out an assertion as presumptively silly. For all the generalist knows, Twinkies may be the work of the devil.

The problem is even more difficult than my examples thus far suggest, for the learning of other disciplines bears not only upon the application of legal rules, but also upon the formulation of those rules. To be sure, a judge framing a legal rule is not dependent on the particular experts provided by litigating parties. The entire Library of Congress is available, but even a judge with the inclimation and time to examine that literature would not often find the answers he needed. Professor Davis has suggested that Congress create a research service for the Supreme Court. ${ }^{11}$ Unfortunately, few of the theoretical and empirical inquiries deemed interesting by other disciplines are directly relevant to the law.

10. See Henning, The Psychiatrist in the Legal Process: Caught in the Seamless Web, in BY REASON OF INSANITY 217, 220 (L. Freedman ed. 1983).

11. See Davis, Judicial, Legislative, and Administrative Lawmaking: A Proposed Research Service for the Supreme Court, 71 MiNN. L. REv. 1, 17 (1986). 
One has to tease the relevant concepts and information out of them in order to answer the question posed by the law. For example, until Donald Turner and I attempted a decade ago to bring economic learning to bear on antitrust law's concern with predatory pricing, ${ }^{12}$ economists had not given much direct attention to that issue. And if scholarship elsewhere provides relevant materials, the lack of a consensus forces the legal observer to pick, choose, and discriminate among economic writings pointing in different directions. Of course, the better litigators make themselves masters of a field, and may learn whatever is to be learned about an industry and about, say, the medical aspects of a drug or other product. But even when the hitigants direct the court's attention to relevant literature, the judge will seldom feel confident in handling other disciplines' disputes.

Where then does he turn? Perhaps to his law clerk. On one occasion, a judge appoimted a "neutral" expert as his law clerk. When sitting on the monopoly suit against the Umited Shoe Company in the early 1950s, Judge Wyzanski engaged Professor Carl Kaysen, a Harvard economist, as his "clerk" to help him bring economic analysis to bear on the factual and legal issues of that case. The judge got the benefit of economics and the professor got a book about the case. ${ }^{13}$ It is interesting to speculate whether the result in United Shoe would have been different had the judge engaged a different expert. Any judge-appoimted expert is neutral in the sense of not being in the pay of either side, but would hardly be entirely free of predispositions or even conclusions on matters within his discipline.

In any event, such a direct plug into another profession is rare. The connection is usually more indirect. Immediately handy to the judge are recent law graduates serving as conventional law clerks. They are bright, have recently been exposed to the imcreasingly interdisciplinary learning at law schools, may have absorbed some of it, and may even have studied, say, economics as undergraduates or graduates. One can see their handiwork. A judge whose published opimons have exhibited hittle attention to economics will release an opmion reveling in the dismal science and then return next year to his prior style. Naturally, the results vary, and one can find errors in even some of the better examples of such law clerk artifacts. Law clerks seem an imperfect vehicle for the reception of other disciplines into the law.

12. See Areeda \& Turner, Predatory Pricing and Related Practices Under Section 2 of the Sherman Act, 88 HaRv. L. REV, 697 (1975); see also 3 P. AREedA \& D. TURNER, ANTITRUST LAw $\emptyset$ 711 (1978).

13. C. KAYSEN, UNTTED STATES V. UNITED SHOE MACHINERY CORPORATION: AN ECONOMIC ANALYSIS OF AN ANTI-TRust CASE (1956). 
Of course, judges might eliminate the middleman and take classes themselves. The Federal Judicial Center and the various circuit conferences have organized seminars, sometimes mcluding persons from other disciplines or law professors informed about those disciplines. And judges often attend bar or law school prograins that may illuminate such matters. Recently, moreover, the bench has received a significant number of acadernics specializing in law and economics. In the main, however, judges will continue to rely upon legal scholars to synthesize law with the learning of other disciplines.

\section{III}

The implications for legal education have long been recognized. As Brainerd Currie wrote in the early fifties, "every available resource of knowledge and judgment must be brought to the task" of legal education. ${ }^{14}$ He saw that

an understanding of the social structure in which law operates can no longer be taken for granted or regarded as irrelevant; law studentsand hence law teachers-must acquire that understanding, and inust somehow learn to take into account the contributions which other disciplines and sciences can make to the solution of social problems. ${ }^{15}$

He did not claim that this msight was new, but saw it as the philosophy "of the sociological jurisprudence which Dean Pound's eloquent interpretation had made familiar." 16

It is now so widely recognized that everything bearimg on the solution of social problems bears on what we study and teach in the law schools that one of my younger colleagues regards every expenditure for a book, newspaper, magazine, or opera as a business expense. More significantly, this recogmition has created a crisis of confidence in what law teachers do. They know that they are not sociologists, philosophers, psychiatrists, political scientists, real scientists, or economists. Yet they are also aware of the incoinpleteness of legal doctrine considered in isolation from the learning of those other fields. If law teachers once gave too little attention to other disciplines, some of them now give too much. Not only are inany academic lawyers practicing these other fields without a license, many do so without appropriate training or rigor.

To provide greater professionahsm in those fields, law schools are becoining mini-universities themselves. Resident psychiatrists and economists have become common; sociologists, if not philosophers and statisticians, may soon follow. Will dilettantism also follow as psychiatrists

14. Currie, The Materials of Law Study, 3 J. LEGAL Educ. 331, 334 (1951).

15. Id. at 355.

16. Id. 
write about law and lawyers about economics, each without sufficient expertise in the other's field? Moreover, although masters of other disciplines have much to teach us, the law's objectives and materials include more than the other disciplines. Antitrust law is more than economics. The law of criminal responsibility is more than psychiatry.

It is generally supposed that the purpose of criminal law is to instruct citizens how they ought to behave and to deter them from behaving otherwise, to exact retribution for misbehavior, and to incapacitate wrongdoers from further disturbing the public peace. In the light of these purposes, the law has long absolved from criminal responsibility the person who, at the time of his offense, was insane in the sense of being unable to distinguish right from wrong. Both retribution and instruction seem poimtless for such a person. In past centuries, moreover, failing to convict the imsane hardly left dangerous persons free to continue threatening the peace, since those perceived to be dangerous were readily locked up. Such confinement is no longer so easy, and the moral concept of an inabihity to distinguish right from wrong has been replaced with a more general exculpatory notion of "Inental illness." In the process, the law has sometimes abdicated its judgment in favor of psychiatrists, who are asked to testify not only on their medical opinions but often on the ultimate question of criminal responsibility.

It should be obvious, however, that the ultimate question for the criminal law is not a medical one. Rather, it is a question of social policy about which psychiatrists are not more expert-and perhaps less sothan philosophers or judges. For example, if conviction is the ouly practical and rehable way of removing from the streets those who have demonstrated their dangerousness by killing others, then perhaps such persons shonld be convicted. Without necessarily advocating that legal rule, I suggest that the legal judgment may be informed by medical factors but is not dictated by them. Such organizations as the American Psychiatric Association have correctly insisted that psychiatrists should not be asked to answer the ultimate question of legal responsibility. ${ }^{17}$

To take a different field, the relevance of economics to public utility regulation and to antitrust law has been so well and so long recognized that it is often difficult to identify what is peculiarly economics as distinct from law. This is hardly surprising, for economics is, in part, a distillation of well-understood human experience. Economists may speak a loftier, or at least a more technical, language, but antitrust judges and

17. American Psychiatric Association, Statement on the Insanity Defense (Dec. 1982), reprinted in American Psychiatric Ass'N, Issues In Forensic Psychiatry 1, 20 (1984). 
writers have never had any difficulty in seeing the evils of cartel price fixing, without inuch need for technical input.

At the saine time, the economists' theoretical structures provide an analytical frainework for thinking about competitive effects, for seeing connections and inpacts that lay intuition would not see, and for showing that some supposed connections are not what they seem. Nevertheless, it is surprising how few confident answers economics provides to the law's questions. One reason is that the practical issues posed by the law are uninteresting to inany econoinists, who would rather build abstract models, simply assuming away much of the untidy reality witl which the law deals. Indeed, soine economists-and especially some lawyers who use econonists-insist upon deducing categorical propositions from simple models of perfect competition when few markets fit that model. They may favor the powerful generalizations drawn from the simple model over inore particular einpirical mquiries probing how certain markets actually work. And when empirical studies are made, interpreting their conclusions and inplications in light of the law's purposes may require more than econoinic sophistication.

The needs and purposes of the law are not necessarily the same as the interests and objectives of the expert pursuing his own discipline. A particular statute or decisional rule may be intended to maximize some value otlier than one that an economist would maximize. The proper legal result may turn on statutory interpretation, cliaracteristics of the legal systein, or other matters of policy on whicl economic science has little to contribute. It is for those reasons that outside disciplines are not the law, but only illuminate it.

For example, it is widely said that the antitrust laws were designed to achieve social and political objectives other than efficient and innovative production at prices near cost. To the extent that this position is correct-a question I do not pursue today-it would mean that the premises and objectives of economics differ from those of the law, although economics would continue to inform the application of the antitrust laws. Even wlien adjusted for the law's policy objectives, moreover, the learning of otler disciphines needs furtlier adjustinent to meet such imperatives of the legal system as fairness, acceptability, stability, predictability, consistency of application, and reasonable admimistrability where trutl is obscure.

Without pursuing the many subtleties of these legal imperatives, let me add these coinments. First, when sanctions are severe, it could be unfair to expand the definition of an offense in response to economic perceptions. For example, the basic provision of the antitrust statute condemns certain conspiracies, which undoubtedly mclude sucli tácit 
conspiracies as a meeting of the minds reached without express words of promise or agreement. ${ }^{18}$ Such conspiracies are also captured by the economists' typical word "collusion," although their phrase "tacit collusion" embraces far more than lawyers or laymen custoinarily understand by their conventional term "tacit conspiracy." The economists' embrace is wider because they are describing a conspiracy-like effect, while lawyers not only worry about the legislators' meaning but also about the fairness of imposing severe sanctions on parties' market behavior that lacks more traditional badges of personal culpability. Incidentally, when those in different fields attach different meanings to similar words, confusion and misunderstanding are likely unless the listeners are sensitive to the differences.

Second, stability and acceptability are also more important to the law in action than to contemplative scholarship, which prizes intellectual innovation. Scholars welcoine each fragment of what is new and, when necessary, cheerfully revise their views of sound policy. The law, however, is slower to change, insisting upon a modicum of fidehty to precedent. Stability allows citizens to plan their affairs, protects reasonable reliance, and spreads among citizens, lawyers, hitigators, and judges a common understanding of the rules governing their decisions.

In addition, the new is not always true or perceived to be true. The latest economic theory or empirical study may seeln right enough to its author, but there is an inevitable lag before it becomes widely accepted by economic or legal scholars. Not only will the latter need the comfort of review and at least some more general acceptance among economists, but citizens will not perceive the law to be just if it accepts the unduly novel or if judges schooled in law and economics base their judgments too much on their own, not generally accepted, perceptions. Of course, we pay a price for this relative stability: the law will lag behind the external disciplines on which it draws. In some cases, by the time a consensus einerges, it will be obsolete.

Finally, clarity of rule is also far more important to the law than it is to other disciplines. The psychologist or economist inainly seeks to construct a theory or to explain behavior. Whether his conclusions lead to a legal prescription or help apply one is not his first order of business. By contrast, the business of the law is to resolve disputes, to divert private decisions away from socially undesirable ends, and sometimies to channel them toward desirable objectives. Thus, external learning needs to be translated or applied to the law's purposes. More importantly, it must often be simplified for incorporation in a legal rule that is clear enough to 
tell citizens what they are supposed to do, or not do, and to tell courts or juries how they can resolve the disputes before them with reasonable confidence and without mentally flipping a coin.

These imperatives of operating a legal system are not the exclusive intellectual property of lawyers. After all, economists can try their hands at formulating administrable legal rules, although they tend to be less sensitive to the needs of the law than are legal scholars.

How is the necessary synthesis to be achieved? Economists are not as good as lawyers at responding to the purposes of the law and the complexities of running a legal system. Lawyers are not as good as economists in doing what economists do or in evaluating what they do. Increasingly common are law professors professionally trained in other disciplines. Even more common are lawyers who, though lacking a graduate license elsewhere, have made themselves familiar enough with another field to know something of its hiterature, something of new developments, and a partial capacity to appraise such developments. Perhaps the most promising vehicle for synthesis is collaboration between professionals who complement each other in bringing two disciplines to bear on a single problem.

Even better is dialogue ainong members of different professions in academic journals. For example, a lawyer might pursue a legal issue with the aid of his understanding of economics, publishing his conclusions. When the topic sufficiently interests economic professionals, they respond in legal or economic journals, with further responses by the original author, and with other lawyers and economists joming in through publications of their own. In some respects, the result is a mess in that non-experts such as judges do not know what to make of the dialogue. Nevertheless, the process is constructive and, at its best, inoves to an increasingly confident synthesis.

I suspect that this process will be the wave of the future, in which experts in various disciplines join issue in academic journals and thus move forward the reception of other disciplines into the law.

\section{IV}

To sum up: (1) Although laymen often view the law as a self-contained mystery, the law addresses life and depends for its content and application on all that is known about humanity, society, and the economy. It therefore borrows heavily from philosophy, sociology, political science, economics, and much more.

(2) Nevertheless, dependent as we are on other disciplines, the law possesses distinctive characteristics and needs that prevent us from turn- 
ing the whole business over to economists, psychiatrists, or other professionals. Their disciplines are not the law; rather, they inform the law.

(3) Our borrowing from and dependence upon the arts and sciences involves difficult problens of translating their knowledge and understanding so that they can be received into the law. Expert witnesses are a helpful vehicle, though a seriously inadequate one. Law clerks are another vehicle, though one of qualified reliability. Judges theinselves often seek advanced learning in other disciplines, though no judge can become adequately versed in all the subjects encountered by courts of general jurisdiction. Inevitably, therefore, legal scholars are the law's primary nexus with the arts and sciences.

(4) To satisfy that office, law professors must be conversant with other fields, but without overestimating their own expertise there and without surrendering their concern with and understanding of the law's purposes and the imperative of operating a fair, just, and relatively efficient legal systein. It would be a tragedy to replace narrow lawyers with lawyers who know other disciplines more than they understand the needs of the legal systein. We need lawyers who understand the purposes and needs of the law and who can use the learning of other disciplines to formulate and revise legal rules and to apply thein to the uncertain reality in which we live.

(5) Like other lenders, experts in other fields may regard legal borrowers condescendingly, for errors will sonetimes occur in transmission, and the law can seldom use all the subtleties and refineinents of other disciplines. While the other disciplines seek truth for its own sake, the law is more skeptical about finding it and uses ouly as much of it as is helpful to guide our prudential policy cloices in this untidy world. 